\title{
The Heart Reinnervates After Transplantation
}

\author{
David A. Murphy, MD, Gregory W. Thompson, BSc, Jeffrey L. Ardell, PhD, \\ Rollin McCraty, Robert S. Stevenson, BS, Virgilio E. Sangalang, MD, \\ René Cardinal, PhD, Michael Wilkinson, PhD, Sylvia Craig, DVM, Frank M. Smith, PhD, \\ John G. Kingma, PhD, and J. Andrew Armour, MD, PhD \\ Departments of Surgery, Pathology, Physiology and Biophysics, and Obstetrics and Gynecology, Dalhousie University, Halifax, \\ Nova Scotia, Canada; Department of Pharmacology, East Tennessee State University, Johnson City, Tennessee; Department of \\ Pharmacology, Université de Montréal, Montréal, Québec, Canada; Department of Cardiology, Laval University, Québec City, \\ Québec, Canada; and the Institute of HeartMath, Boulder Creek, California
}

Background. Whether cardiac reinnervation occurs after transplantation remains controversial. If reinnervation does occur, how sympathetic and parasympathetic efferent neurons do this remains unknown.

Methods. Power spectral analysis of heart rate variability was assessed for 1 year after cardiac autotransplantation in 9 dogs. After induction of anesthesia 13 months after transplantation, cardiac and intrinsic cardiac neuronal responses elicited by both electrical stimulation of parasympathetic or sympathetic efferent neurons and systemic or local coronary artery administration of nicotine $(5 \mu \mathrm{g} / \mathrm{kg})$, angiotensin II $(0.75 \mu \mathrm{g} / \mathrm{kg})$, and tyramine $(1.2 \mu \mathrm{g} / \mathrm{kg})$ were studied. The transmembrane electrical properties of intrinsic cardiac neurons were studied in vitro. Ventricular tissue catecholamine content, $\alpha$-tubulin expression, and $\beta$-adrenergic receptor density and affinity were studied. The presence of axons crossing suture lines was sought histologically.

Results. Nerves were identified crossing suture lines. Electrical or chemical (ie, nicotine or angiotensin II) activation of sympathetic efferent neurons enhanced cardiodynamics, as did tyramine. Stimulating vagal efferent preganglionic axons induced bradycardia in half of the dogs. Functional reinnervation did not correlate with

$\mathrm{W}$ hether cardiac reinnervation occurs after transplantation remains controversial despite extensive anatomic, physiologic, and pharmacologic testing. Further, those studies reporting reinnervation after transplantation have not elucidated the extent to which each limb of the autonomic efferent nervous system influences the transplanted heart.

Absence of alterations in cardiac chronotropism and inotropism in response to atropine, amyl nitrate, tyramine, or noninvasive reflex testing support the thesis that afferent [1] and efferent [2-5] neurons do not reinnervate the transplanted human heart. Ultrastructural evidence also indicates that the human heart does not reinnervate up to 12 years after transplantation [6]. Loss of heart rate variability, as assessed by power spectral analysis, during

Accepted for publication Nov 19, 1999.

Address reprint requests to Dr Armour, Department of Physiology and Biophysics, Dalhousie University, Halifax, NS, B3H 4H7, Canada. specific power spectra derived from rate variability in the conscious state. Responding to nicotine and angiotensin II in situ, transplanted intrinsic cardiac neurons generated spontaneous activity. These neurons displayed nicotine-dependent synaptic inputs in vitro. Ventricular tissue had normal $\beta$-adrenergic receptor affinity and density but reduced catecholamine and $\alpha$-tubulin contents.

Conclusions. The intrinsic cardiac nervous system receives reduced input from extracardiac sympathetic efferent neurons after transplantation and inconsistent input from parasympathetic efferent preganglionic neurons. These heterogeneous neuronal inputs are not reflected in heart rate variability or ventricular $\beta$-adrenergic receptor function. Transplanted angiotensin IIsensitive intrinsic cardiac neurons exert greater cardiac control than do nicotine-sensitive ones. The intrinsic cardiac nervous system remodels itself after cardiac transplantation, and this indicates that direct assessment of extracardiac and intrinsic cardiac neuronal behavior is required to fully understand cardiac control after transplantation.

(Ann Thorac Surg 2000;69:1769-81) (C) 2000 by The Society of Thoracic Surgeons

the first years after cardiac transplantation has been interpreted as indicating that there is a withdrawal of autonomic innervation of that organ postoperatively [7]. In addition, discordance between recipient and donor sinus nodal function [3] and the altered capacity of the transplanted versus normal left ventricles to develop pressure [4] have been interpreted as suggesting sustained cardiac denervation after transplantation. Thus, there exists considerable evidence that supports the thesis that the transplanted heart does not reinnervate.

Conversely, there is direct and indirect evidence indicating that efferent autonomic neuronal reinnervation occurs within 1 year after cardiac transplantation. For instance, data derived from direct electrical stimulation

This article has been selected for the open discussion forum on the STS Web site:

\section{http://www.sts.org/section/atsdiscussion/}


of cardiac autonomic efferent nerves imply that the transplanted canine heart is completely reinnervated by 12 months postoperatively [8-10]. In agreement with that finding, transplanted hearts have been reported to display normal augmentor responses to tyramine-induced release of sympathetic postganglionic norepinephrine stores [11]. In addition, heart rate variability [12, 13] and other autonomic function testing [8,9], including scintigraphic assessment of metaiodobenzylguanidine myocardial uptake [14], indicate that complete autonomic reinnervation occurs within a year after cardiac transplantation. Studies also suggest that parasympathetic efferent neurons reinnervate the transplanted heart with lesser [15] or greater [10] consistency than do sympathetic efferent neurons. Thus, despite the fact that much of the recent evidence indicates that cardiac reinnervation occurs by 1 year after transplantation, the status of such reinnervation remains controversial.

In addition to parasympathetic efferent postganglionic neurons [16], the intrinsic cardiac nervous system contains afferent neurons [17], local circuit neurons [18], and sympathetic efferent postganglionic neurons [19]. The intrinsic cardiac nervous system is known to retain some function after acute [20] or chronic [17] decentralization. Further, it is known that this nervous system is capable of influencing regional cardiodynamics after acute cardiac transplantation [20]. The role that this nervous system subserves in maintaining cardiac function after longterm cardiac transplantation remains unknown.

The present study was undertaken to determine whether sympathetic and parasympathetic efferent neurons reinnervate the mammalian intrinsic cardiac nervous system by 1 year after cardiac transplantation. If reinnervation does occur, we sought to determine the functional capacity of sympathetic versus parasympathetic efferent neurons to influence cardiodynamics 1 year postoperatively. We also sought to determine whether heart rate variability, as assessed by power spectral analysis throughout the year after transplantation, correlates to the patterns of functional reinnervation by sympathetic and parasympathetic efferent neurons. Whether the intrinsic cardiac nervous system remodels itself after cardiac transplantation was also examined by studying cardiac responses elicited by chemical activation of transplanted intrinsic cardiac neurons.

In conjunction with these in situ studies, the electrophysiologic properties of such intrinsic cardiac neurons and the presence of nicotine receptor inputs to them were studied in vitro. Histological analysis for the presence of nerves coursing over suture lines was undertaken. Ventricular myocyte catecholamine content, $\alpha$-tubulin expression, and $\beta$-adrenergic receptor affinity and density were quantified to correlate possible reinnervation patterns with alterations in cardiac myocyte function. In this manner, we sought to characterize not only the degree to which the mammalian heart reinnervates by 1 year after transplantation but also whether the intrinsic cardiac nervous system remodels itself in such a state.

\section{Material and Methods}

All animals received humane care in compliance with the "Principals of Laboratory Animal Care" and the "Guide for the Care and Use of Laboratory Animals" prepared by the National Institutes of Health (NIH publication 85-23, revised 1985).

\section{Surgical Procedure}

Eighteen mongrel dogs of either sex and weighing 19 to $25 \mathrm{~kg}$ were sedated with Pentothal (sodium thiopental) (12 to $15 \mathrm{mg} / \mathrm{kg}$ intravenously). After intubation, anesthesia was induced with $4 \%$ halothane in oxygen using a volume-regulated respirator. The heart was exposed through an incision in the left fourth interspace. Once cardiopulmonary bypass had been initiated, direct cannulation of the inferior vena cava using a shortened $21 \mathrm{~F}$ femoral artery cannula was performed. The ascending aorta was cleared of fat and cross-clamped, and cold crystalloid cardioplegic solution was infused into the proximal aorta for approximately 10 minutes.

Once the coronary vascular tree was cleared of blood, the heart was excised and placed in room-temperature sterile saline solution. In the first 3 animals, the sinoatrial node was left attached to the superior vena cava, which was not removed with the heart. In an attempt to minimize the development of major bradydysrhythmias during the early postoperative period that resulted in systemic vascular hypotension, the sinoatrial node was excised with the heart in the remaining animals. Temporary pacing wires were placed on the epicardial surfaces of the right atrium and the right ventricle so that the hearts could be paced electrically at approximately 80 beats per minute (bpm). After cardiac reimplantation and the institution of cardiac pacing, cardiopulmonary bypass was discontinued. The thorax was closed and air withdrawn from the thoracic cavity.

\section{Postoperative Management}

Pain management and postoperative care were instituted for 48 hours. At some time during the first 12 hours, the chest tube was removed and intravenous therapy discontinued. Once it was confirmed that heart rate could be maintained at an adequate level, the pacemaker leads were withdrawn 1 day to 4 days after autotransplantation. In 4 animals, cardiac pacing was required for 2 weeks after transplantation to prevent the occurrence of bradydysrhythmias. Nine animals survived for more than 1 year.

\section{Power Spectral Analysis of Heart Rate Variability}

The 9 dogs that survived for a year after cardiac autotransplantation underwent Holter monitoring of electrocardiograms (ECGs) for 24-hour periods at 3, 6, 9, and 12 months postoperatively with a Reynolds Medical Sherpa model 2 portable tape recorder (Aventric Technologies, Inc, Madison Heights, MI). Electrocardiographic data obtained over these 24-hour periods were analyzed offline by means of a computer. The electrocardiographic signals were sampled at $256 \mathrm{~Hz}$ so that heart rate, 
electrocardiographic abnormalities, and power spectral data on heart rate variability could be analyzed continuously over 24-hour periods. The R wave of the ECG was detected from the electrocardiographic signals, and instantaneous heart rate time series were constructed at $4 \mathrm{~Hz}$ [21]. Power spectra of heart rate signals were derived for each data collection period in each animal at $3,6,9$, and 12 months after cardiac autotransplantation. Holter monitoring of the ECG over 24-hour periods was also performed on 3 control dogs (without operation) to obtain comparison data.

\section{Animal Preparation for Physiologic Experiments}

Thirteen months after transplantation, the 9 surviving dogs were sedated with Pentothal (12 to $15 \mathrm{mg} / \mathrm{kg}$ intravenously) and intubated. Positive-pressure ventilation was initiated and maintained with a Bird Mark 7A ventilator using a gas mixture of $95 \%$ oxygen and $5 \%$ carbon dioxide for the duration of the experiments. The dogs were anesthetized with Pentothal $(5 \mathrm{mg} / \mathrm{kg}$ intravenously to effect every 5 to 10 minutes) during the surgical procedure. Heart rate was monitored continuously throughout the experiments with a lead II ECG. After completion of the surgical procedures, anesthetic was changed to $\alpha$-chloralose, administered first as a bolus ( $25 \mathrm{mg} / \mathrm{kg}$ intravenously) and then as repeat doses (15 to $20 \mathrm{mg} / \mathrm{kg}$ intravenously) every hour or less throughout the experiments, as required. Noxious stimuli were applied occasionally to a paw throughout the experiments to ascertain the adequacy of anesthesia.

\section{Recording Cardiac Indices}

As reported previously [18], atrial pressure was monitored with a PE-50 catheter placed in the left atrial chamber and left ventricular chamber pressure, with a Cordis $8 \mathrm{~F}$ pigtail catheter inserted into the left ventricular chamber. Aortic pressure was measured using a catheter placed through the other femoral artery. These catheters were connected to Bentley Trantec model 800 transducers. Miniature solid-state pressure transducers (model P19 measuring $5 \mathrm{~mm}$ in diameter $\times 1.2 \mathrm{~mm}$ in thickness; Konigsberg Instruments Inc, Pasadena, CA) were inserted into the midwall regions of the right ventricular conus and the ventral wall of the left ventricle to record regional intramyocardial pressures. Two sets of bipolar electrodes were sutured to the ventral epicardial surface of the right atrium, one set above and the other below the suture line so that atrial pacing could be performed cranial and caudal to the atrial suture line. All data, including a lead II ECG, were recorded on an Astro-Med model MT 9500 eight-channel rectilinear recorder (AstroMed, West Warwick, RI) and stored on VHS tape using a videocassette recorder (model 820; A.R. Vetter Co, Rebersburg, PA) for later analysis. Body temperature was maintained constant throughout the experiments by means of a temperature-regulated circulating hot water pad. A PE-50 catheter was inserted into a branch of the right coronary artery that arises immediately proximal to the coronary artery branch supplying blood to the right atrial ganglionated plexus and secured in place by liga- tures, thereby ensuring that infused chemicals could be delivered to the artery perfusing the right atrial ganglionated plexus and other distal tissues.

\section{Experimental Design}

The following four interventions were performed:

Acutely decentralized right and left stellate ganglia were stimulated individually with supramaximal electrical stimuli $(10 \mathrm{~V}, 5 \mathrm{~ms}, 10 \mathrm{~Hz})$ for 20 seconds using bipolar electrodes attached to a Grass SD-9 square wave stimulator, the output of which was monitored on a Telequipment D-54 oscilloscope.

Each cervical vagosympathetic complex was divided; the caudal end of each was stimulated individually ( $15 \mathrm{~V}$, $5 \mathrm{~ms}, 20 \mathrm{~Hz}$ ) for 20 seconds using bipolar electrodes.

Chemicals, obtained from Sigma Chemical Co (St. Louis, MO) and BDH (Toronto, ON, Canada), were given in pharmacologic doses. Nicotine (free base $(-)$ nicotine, $5 \mu \mathrm{g} / \mathrm{kg})$, angiotensin II $(0.75 \mu \mathrm{g} / \mathrm{kg})$, and tyramine $(1.2 \mu \mathrm{g} / \mathrm{kg})$ were administered individually into the regional arterial blood supply of ventral right atrial neurons. Thereafter, each chemical was administered in the same dosages into the superior vena cava. At least 5 minutes was allowed to elapse between each intervention for the preparation to return to baseline conditions. As generalized depression of cardiovascular indices occurred when the $\beta$-adrenergic receptors agonist isoproterenol hydrochloride was administered systemically in 2 animals tested, this agent was not used further. Once the procedures described had been completed, the right and left stellate ganglia were stimulated again, as were the distal right and left cervical vagosympathetic complexes.

Thereafter, the right atrium was paced cranial and then caudal to the suture line by means of the two sets of pacing electrodes already described. Electrical stimuli $(1 \mathrm{~V}, 0.1 \mathrm{~ms})$ were delivered at a rate $10 \mathrm{bpm}$ higher than the natural rate of atrial contraction for 1-minute periods. The time required for atrial tissues above and below the suture line to begin to generate a contraction spontaneously after pacing was recorded.

\section{Intrinsic Cardiac Neurons Studied In Vivo}

The activity generated by ventral ventricular neurons was recorded in 4 animals by means of a tungsten microelectrode with a $250-\mu \mathrm{m}$ diameter and an exposed tip of $10 \mu \mathrm{m}$ (impedance, 9 to $12 \mathrm{M} \Omega$ at 1,000 Hz) (model ME 25-10-2; Frederick Haer \& Co, Brunswick, ME), as described elsewhere [18]. The reference electrode was attached to the pericardium and the ground electrode, to adjacent subcutaneous fatty tissue. Electrical activity generated by ventricular neurons was differentially amplified by a battery-powered amplifier, and the output of this device was further amplified (50 to $200 \times$ ) and filtered (band width, $100 \mathrm{~Hz}$ to $2 \mathrm{kHz}$ ) by means of an optically isolated amplifier (Applied Microelectronics Institute, Halifax, NS, Canada). Using these techniques and criteria, the microelectrode does not record action potentials generated by axons of passage; rather it records action potentials generated by somata, dendrites, or both [18]. As fluctuations in the amplitude of action potentials were 
found to vary by less than $10 \mu \mathrm{V}$ over several minutes, action potentials recorded in a given locus with the same configuration and amplitude were considered to be generated by a single unit. Action potentials with signal to noise ratios greater than 3:1 were analyzed.

\section{Whole-Animal Data Analysis}

Heart rate, left atrial systolic pressure, right and left ventricular intramyocardial systolic pressures, and left ventricular chamber systolic pressure were measured for ten consecutive beats. The activity generated by the neurons recorded in 4 animals was averaged over 30second periods. The means ( \pm the standard error of the mean) of data were calculated for the period immediately prior to an intervention and during maximum elicited responses. These data were then compared using twoway analysis of variance with repeated measures, followed by Fisher's protected least significant difference test ( $p$ values of $<0.05$ and 0.01 were used). With respect to power spectral analysis of the heart rate variability (HRV) signals, power in the range of 0.0033 to $0.04 \mathrm{~Hz}$ was considered very low frequency; 0.04 to $0.15 \mathrm{~Hz}$, low frequency; and 0.15 to $0.5 \mathrm{~Hz}$, high frequency.

\section{Intrinsic Cardiac Neurons Studied In Vitro}

Immediately after terminating these experiments, the right or left atrial ganglionated plexus was removed from 7 dogs and placed in oxygenated physiological saline solution in a temperature-regulated bath. A HEPESbuffered Tyrode's solution superfused these tissues; the solution contained the following in millimoles per liter: $\mathrm{NaCl}, 120.5 ; \mathrm{KCl}, 3.8 ; \mathrm{KH}_{2} \mathrm{PO}_{4}, 1.2 ; \mathrm{MgSO}_{4}$, 1.2; glucose, 11.1; HEPES, 10; adjusted to a $\mathrm{pH}$ of 7.4 with $\mathrm{NaOH}$. The transmembrane properties of identified intrinsic cardiac neurons were recorded with conventional microelectrodes (resistance of 40 to $60 \mathrm{M} \Omega$ ) filled with $2.4 \mathrm{~mol} / \mathrm{L}$ $\mathrm{KCl}$. An $\mathrm{Ag}-\mathrm{AgCl}$ bridge connected the pipette to the input stage of an Axoclamp-2A amplifier (Axon Instruments, Burlingame, CA). Neurons were activated using $0.5 \mathrm{nA}$ and $0.4 \mathrm{~Hz}$ pulses, the duration of which ranged from 5 to $100 \mathrm{~ms}$. The evoked synaptic inputs to identified neurons were examined by delivering electrical stimuli ( 1 to $4 \mathrm{~mA}, 0.1 \mathrm{~ms}, 0.01 \mathrm{~Hz}$ ) to each of the nerves connected to the ganglia containing investigated neurons before and after administration of the nicotine-receptorblocking agent hexamethonium chloride $(100 \mu \mathrm{mol} / \mathrm{L})$ by way of the fluid superfusing the tissue bath (volume of $0.5 \mathrm{~mL}$ at a rate of $3 \mathrm{~mL} / \mathrm{min}$ ).

\section{Histological Analysis}

Tissues, including the sutured anastomoses of the atria, ascending aorta, and pulmonary artery, were removed, washed in normal saline solution, and fixed in $10 \%$ formalin. Serial tissue blocks about $4 \mathrm{~mm}$ thick were prepared from these tissues in such a way that longitudinal sections could be made across their suture lines. Tissue blocks, pretreated with $10 \%$ formic acid to soften the suture material, were processed for paraffin sectioning. Adjacent sections were stained with hematoxylin and eosin or Masson's trichrome or stained for neural tissue using the immunoperoxidase method, which employs monoclonal mouse anti-human neurofilament protein (DAKO-NF, 2F1).

VENTRICULAR TISSUE CATECHOLAMINE CONTENT. When a catheter was placed in the coronary sinus to obtain coronary venous blood samples, left ventricular and aortic systolic pressures fell to such an extent that this procedure had to be terminated. Thus, the release of catecholamines from autotransplanted hearts was not determined. Tissues removed from the left ventricular free wall at the end of each experiment were immediately frozen in liquid nitrogen and stored at $-70^{\circ} \mathrm{C}$. Tissue homogenates $(100 \mathrm{mg})$ derived from these specimens were mixed with $50 \mathrm{mg}$ of acid-washed alumina (aluminum oxide). An internal standard was added (2 $\mathrm{ng} / \mathrm{mL}$ of 3-4 dihydroxybenzylamine). After the addition of $1 \mathrm{~mL}$ of trishydroxymethylaminomethane buffer (Tris) $(1.0 \mathrm{~mol} / \mathrm{L}[\mathrm{pH}$ 8.6]) containing $2 \%$ disodium EDTA (ethylenediaminetetraacetic acid), the mixture was shaken and centrifuged and the supernatant removed. The alumina was washed three times with distilled water, and adsorbed catecholamines were eluted with $200 \mu \mathrm{L}$ of $0.2 \mathrm{~mol} / \mathrm{L} \mathrm{HCl}$. Catecholamine concentrations in these solutions were measured by high-performance liquid chromatography (electrochemical detector).

VENTRICULAR $\beta$-ADRENERGIC RECEPTOR ANALYSIS. Left ventricular tissues obtained at the end of the experiments were stored at $-70^{\circ} \mathrm{C}$ until their $\beta$-adrenergic receptors could be characterized. Left ventricular tissue samples (approximately $4 \times 4 \times 8 \mathrm{~mm}$ ) obtained from 4 study dogs (with transplantation) and 3 control dogs (without transplantation) were placed on the precooled $\left(-20^{\circ} \mathrm{C}\right)$ stage of a McIlwain tissue chopper (The Mickle Laboratory Engineering Co, Gomshall-Mickle, Surrey, England), held in place with Tissue-TEK OCT compound (Sakura Finetek, USA, Inc, Torrance, CA), and allowed to harden $\left(-20^{\circ} \mathrm{C}\right.$ for 2 minutes). Tissue slices $(4 \mathrm{~mm} \times 4 \mathrm{~mm} \times 350 \mu \mathrm{m})$ were cut on a McIlwain chopper stage and placed in Petri dishes containing Dulbecco's phosphate-buffered saline solution (on ice). Consistent myocardial tissue samples obtained from the slices using a 2-mm punch (Fine Science Tools, Vancouver, BC, Canada) were placed into separate wells containing $0.5 \mathrm{~mL}$ of Dulbecco's phosphate-buffered saline solution. A separate group of micropunches ( $\mathrm{n}=$ eight to ten) was weighed for each assay to obtain mean wet weights.

Beta-adrenergic receptor binding was determined using $\left[{ }^{3} \mathrm{H}\right] \mathrm{CGP} 12177$ (44 Ci/mmol; Amersham Life Science, Toronto, ON, Canada). Each tissue was assayed at concentrations in the range of 0.2 to $3.0 \mathrm{nmol} / \mathrm{L}$. Nonspecific binding was determined in the presence of timolol maleate $\left(10^{-5} \mathrm{~mol} / \mathrm{L}\right)$. Labeled and unlabeled drugs were added in $20-\mu \mathrm{L}$ aliquots to give a final assay volume of $540 \mu \mathrm{L}$. Tissues in six micropunches were studied at each concentration to determine total binding, four being studied at each concentration for nonspecific binding. After incubation at $0^{\circ} \mathrm{C}$ for 180 minutes, $50-\mu \mathrm{L}$ aliquots of buffer were removed for determination of free (equilib- 
rium) concentration of $\left.{ }^{3} \mathrm{H}\right] \mathrm{CGP} 12177$. The remaining buffer was removed from the wells by pipette, and the punches were washed (twice for 5 minutes each) with cold Dulbecco's phosphate-buffered saline solution $(0.5 \mathrm{~mL})$ using a Jet-Pipette (Cole-Parmer Instrument Co, Chicago, IL). The wells were drained and the tissues removed by touching with a small square (approximately $1 \mathrm{~mm}$ ) of glass-fiber filter paper (Whatman GF/B, Maidstone, England). Tissues were then placed in vials containing scintillation fluid (1.8 mL; Ecolite ICN, CA), which were thoroughly mixed, and left overnight before being counted in a liquid scintillation counter (efficiency, 51\%). Binding curves of $\left[{ }^{3} \mathrm{H}\right] \mathrm{CGP} 12177$ to tissues were generated by nonlinear regression analysis using a proFIT (Cherwell Scientific, Oxford, England) computer program.

TUBULIN ANALYSIS. Left ventricular tissues were stored at $-70^{\circ} \mathrm{C}$ for subsequent protein content analysis. Total RNA (ribonucleic acid) was isolated from myocardial biopsy specimens obtained from these tissues once they were thawed by homogenization in guanidine thiocyanate and isopyknic centrifugation through cesium chloride. The RNA was kept frozen at $-80^{\circ} \mathrm{C}$ until prepared for electrophoresis. For Northern blot analysis, $10 \mu \mathrm{g}$ of RNA was denatured in glyoxal and resolved by electrophoresis on $1.2 \%$ agarose gels in phosphate buffer (10 $\mathrm{mmol} / \mathrm{L}, \mathrm{pH}$ 7.0). The RNA was transferred by suction onto nylon membranes (Hybond; Amersham Pharmacia Biotech, Baie d'Urfé, PQ Canada) using a vacuoblot apparatus (VacuGene XL; Amersham Pharmacia Biotech), fixed by ultraviolet irradiation for 3 minutes, and heated at $80^{\circ} \mathrm{C}$ for 1.5 hours. Glyoxal was removed by soaking in Tris $\mathrm{HCl}$ buffer $(20 \mathrm{mmol} / \mathrm{L}$; $\mathrm{pH} 8.0)$ at $100^{\circ} \mathrm{C}$ for 10 minutes. The nylon membranes were prehybridized for 4 hours at $65^{\circ} \mathrm{C}$ in $1 \mathrm{~mL} / 5$ to $10 \mathrm{~cm}^{2}$ of prehybridization buffer containing $5 \times$ SSC (saline solutionsodium-citrate, $5 \times$ Denhardt's solution, $50 \mathrm{mmol} / \mathrm{L}$ sodium phosphate $\mathrm{pH} 6.9,250 \mu \mathrm{g} / \mathrm{mL}$ ) of sssDNA (deoxyribonucleic acid), and $0.1 \%$ SDS (sodium dodecyl sulfate). Human $\alpha$ - and $\beta$-tubulin complementary (cDNA) DNA were labeled using the Oligolabelling Kit (Amersham Pharmacia Biotech) and $\left[\alpha{ }^{32} \mathrm{P}\right]$ deoxycytidine $5^{\prime}$-triphosphate (specific activity $>3,000 \mathrm{Ci} / \mathrm{mmol}$ ) (Mandel Scientific, Montreal, PQ, Canada). Membranes were hybridized with radiolabeled probes containing $1 \times$ $10^{6} \mathrm{cpm} / \mathrm{mL}$ of fresh hybridization buffer for 16 hours at $65^{\circ} \mathrm{C}$ and washed twice with SSC/0.1\% SDS for $15 \mathrm{~min}-$ utes each at room temperature and then at $67^{\circ} \mathrm{C}$ for 30 minutes. Membranes were exposed on Kodak BioMax film at $-80^{\circ} \mathrm{C}$ with intensifying screens for detection. Probes were subsequently stripped by boiling membranes in water at $100^{\circ} \mathrm{C}$ for 20 minutes; dehybridized membranes were probed again with ${ }^{32} \mathrm{P}$-labeled $18 \mathrm{~S}$ ribosomal RNA cDNA as internal control. All analyses were done in duplicate from different myocardial biopsy specimens.

PROTEIN ISOLATION AND WESTERN BLOTTING. Tissue samples from at least two different myocardial biopsy specimens from each heart were homogenized in electrophoresis sample buffer (Tris, $11 \mathrm{mmol} / \mathrm{L}$; EDTA, $1.1 \mathrm{mmol} / \mathrm{L} ; 3.3 \%$ SDS; $11 \%$ glycerol; DTT, $40 \mathrm{mmol} / \mathrm{L} ; \mathrm{pH} 8.0$ ) supplemented with protease inhibitors $(5 \mu \mathrm{g} / \mathrm{mL}$ of leupeptin, $5 \mu \mathrm{g} / \mathrm{mL}$ of antipain, $5 \mu \mathrm{g} / \mathrm{mL}$ of pepstatin, $17 \mu \mathrm{g} / \mathrm{mL}$ of phenylmethylsulfoxylfluoride in dimethyl sulfoxide) and centrifuged at $10,000 \mathrm{~g}$ for 15 minutes to remove insoluble material. Total protein content in tissue homogenates was determined using the filter paper dye-binding technique. Proteins were resolved with a denaturing-PAGE $(7 \%$ to $17 \% ; 30: 0.15 \mathrm{wt} / \mathrm{wt}$ acrylamide/bisacrylamide of stock solution) and transferred to Immobilon PDVF membranes (Millipore Corp, Mississauga, ON, Canada). Membranes were preincubated in blocking solution (Boehringer Mannheim, Laval, $\mathrm{PQ}$, Canada) at room temperature and probed with a 1:1,000 dilution of monoclonal antibody to $\alpha$-tubulin (Clone DM1A; Sigma Chemical Co). Bound antibody was visualized with a sheep anti-mouse Ig conjugated to horseradish peroxidase secondary antibody (Roche Diagnostics, Montreal, PQ, Canada) and enhanced chemiluminescence (ECL; Boehringer Mannheim).

\section{Data Acquisition and Analysis}

Cardiac indices derived over 30 -second periods were analyzed before and during peak responses elicited by each intervention. The means $( \pm 1$ standard error of the mean) of cardiac indices were calculated from these data. Action potentials generated by right atrial neurons with the same configuration and amplitude and signal to noise ratios greater than 3:1 were counted for 30-second periods to establish average activity immediately prior to and during maximal responses elicited by each intervention. All data are expressed as the mean \pm the standard error of the mean. One-way analysis of variance with Bonferroni correction for multiple tests were used for statistical analysis. A significance value of $p$ less than 0.01 was used for these determinations.

\section{Results}

\section{Cardiovascular Status After Transplantation}

The condition of 9 animals was stable throughout the 12-month postoperative period. Four dogs died 4 to 12 hours after transplantation of blood loss or other surgical complications; 4 dogs died of bradydysrhythmias within the following 24-hour period; and 1 dog died 1 month after transplantation of a massive pulmonary embolus.

In each of the 9 remaining animals, considerable heart rate variability was identified throughout the year after cardiac autotransplantation while the animals were housed in a comfortable environment (Fig 1). In the conscious state, resting ventricular rates ranged between 26 and $150 \mathrm{bpm}$ over 24-hour periods when analyzed 3, 6, 9, and 12 months after transplantation. Each dog displayed bradydysrhythmias (longest pauses between ventricular beats, 13.2 seconds) lasting from 650 to 927 ventricular beats in the immediate postoperative period and throughout the next 9 months. One year after cardiac 
Fig 1. Holter monitor electrocardiographic data obtained from $(A, B) 2$ conscious animals 1 year after cardiac acute transplantation. The upper and lower panels on the left illustrate data obtained during the slowest $(A, 26 \mathrm{bpm} ; B, 31 \mathrm{bpm})$ and fastest (A, 163 bpm; B, 120 bpm) heart rates in each dog. To the right are power spectral data (PSD) derived from representative 20-minute periods when bradycardia occurred in both animals. These data display similar power spectral peaks despite the fact that the heart of the $\operatorname{dog}$ in A exhibited no evidence of parasympathetic reinnervation, whereas that of the dog in B was reinnervated by parasympathetic efferent neurons.
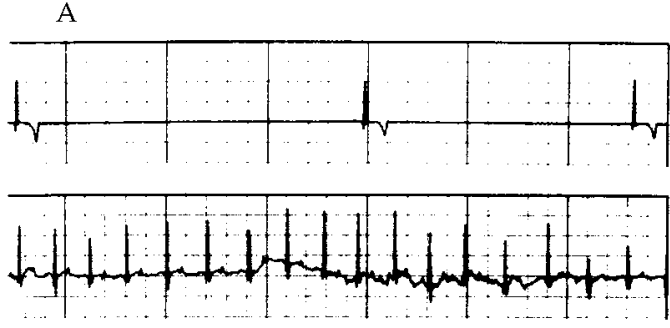

$1 \mathrm{sec}$

B

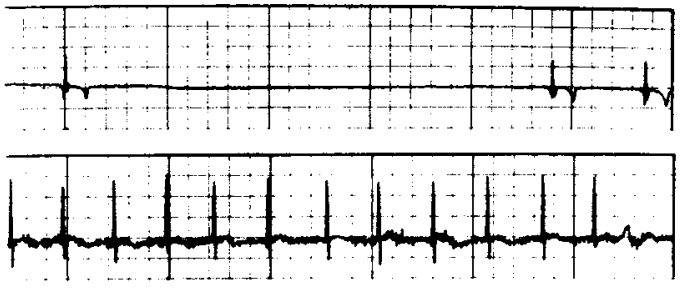

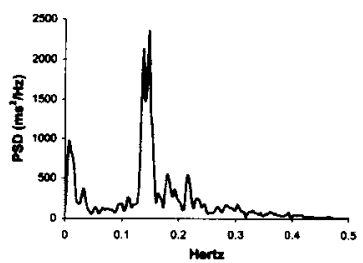

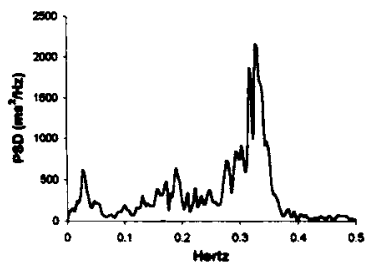

transplantation, the average heart rate of conscious animals monitored during 24-hour periods was $80 \pm 12 \mathrm{bpm}$ (range, 23 to $171 \mathrm{bpm}$ ). At that time, bradydysrhythmias lasting for $227 \pm 89$ beats (range, 5 to 839 beats) occurred with an average ventricular rate of $38 \pm 5 \mathrm{bpm}$ (range, 23-65 bpm). Periods of tachycardia (139 $\pm 9 \mathrm{bpm}$; range, 96 to $171 \mathrm{bpm}$ ), lasting as long as 54 beats, also occurred. Both time domain and power spectral analyses of heart rate variability derived from representative 20-minute epochs over 24 hours at 3, 6, 9, and 12 months after transplantation were similar.

Three control dogs monitored in the same environment had average heart rates of $84 \pm 19 \mathrm{bpm}$ (range, $62 \pm$ 19 to $151 \pm 23 \mathrm{bpm}$ throughout 24-hour monitored periods). In these animals, the mean power in each frequency band was as follows: very low frequency, 8.43; low frequency, 9.54; and high frequency, 10.38. On the other hand, the ECGs of all study animals exhibited junctional rhythms throughout the year after transplantation. No obvious power spectral differences were identified at 3, 6, 9, and 12 months after transplantation. For instance, the mean powers derived from the study dogs 3 and 12 months after operation were as follows: very low frequency, 9.63 and 9.18, respectively; low frequency, 9.69 and 9.40; and high frequency, 9.66 and 9.78.

Twelve months after autotransplantation, none of the time domain or frequency domain measures reflected the degree of cardiac reinnervation subsequently found by direct electrical stimulation of either parasympathetic or sympathetic efferent neurons. Further, the degree of parasympathetic efferent neuronal reinnervation, as assessed in a direct manner, did not reflect the amount of bradycardia encountered in the conscious state. The ECGs generated by the transplanted hearts displayed clear peaks in the HR region of the power spectrum even though many of these animals subsequently were found to have no parasympathetic efferent neuronal innervation as assessed by direct nerve stimulation (Fig 2). In other words, cardiac autotransplantation altered the electrocardiographic patterns generated by the hearts throughout the year after transplantation, including that of their HRV power spectra, whether or not hearts became reinnervated by parasympathetic efferent neurons.

\section{Histological Analysis}

Gross (Fig 3A) and microscopic (Figs 3B-3D) analyses of the suture lines were performed. The sections stained with hematoxylin and eosin and Masson's trichrome
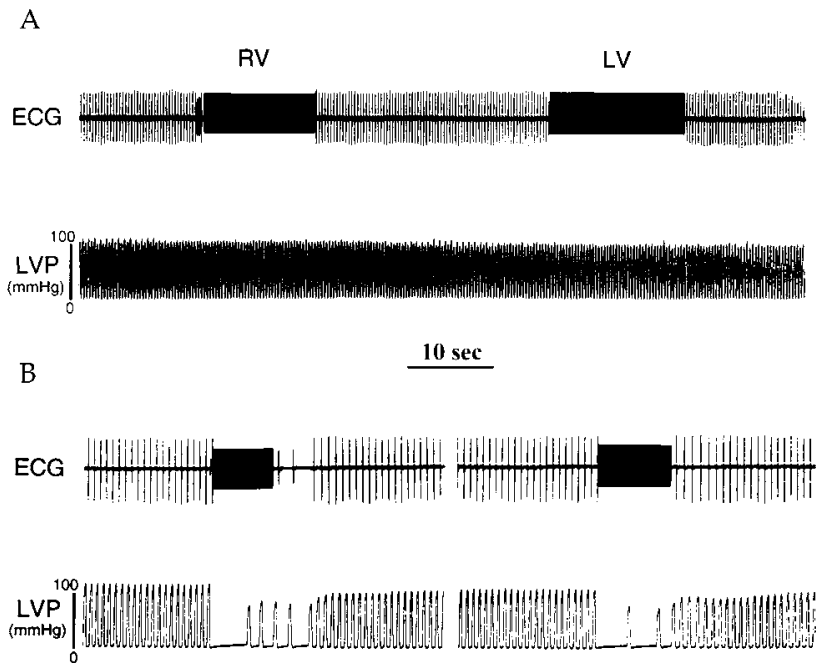

Fig 2. Varied cardiac effects elicited in the 2 dogs in Figure 1 ( $A$ and $B$ represent the same animals) induced by stimulating efferent axons in sectioned right (RV) or left (LV) cervical vagus individually. The times when stimuli were applied to neural tissues are indicated by the solid black sections (stimulus artifacts) recorded in the electrocardiographic traces. Note that bradycardia was elicited in 1 animal (B) but not in the other (A). (ECG = lead II electrocardiogram; LVP $=$ left ventricular chamber pressure.) 

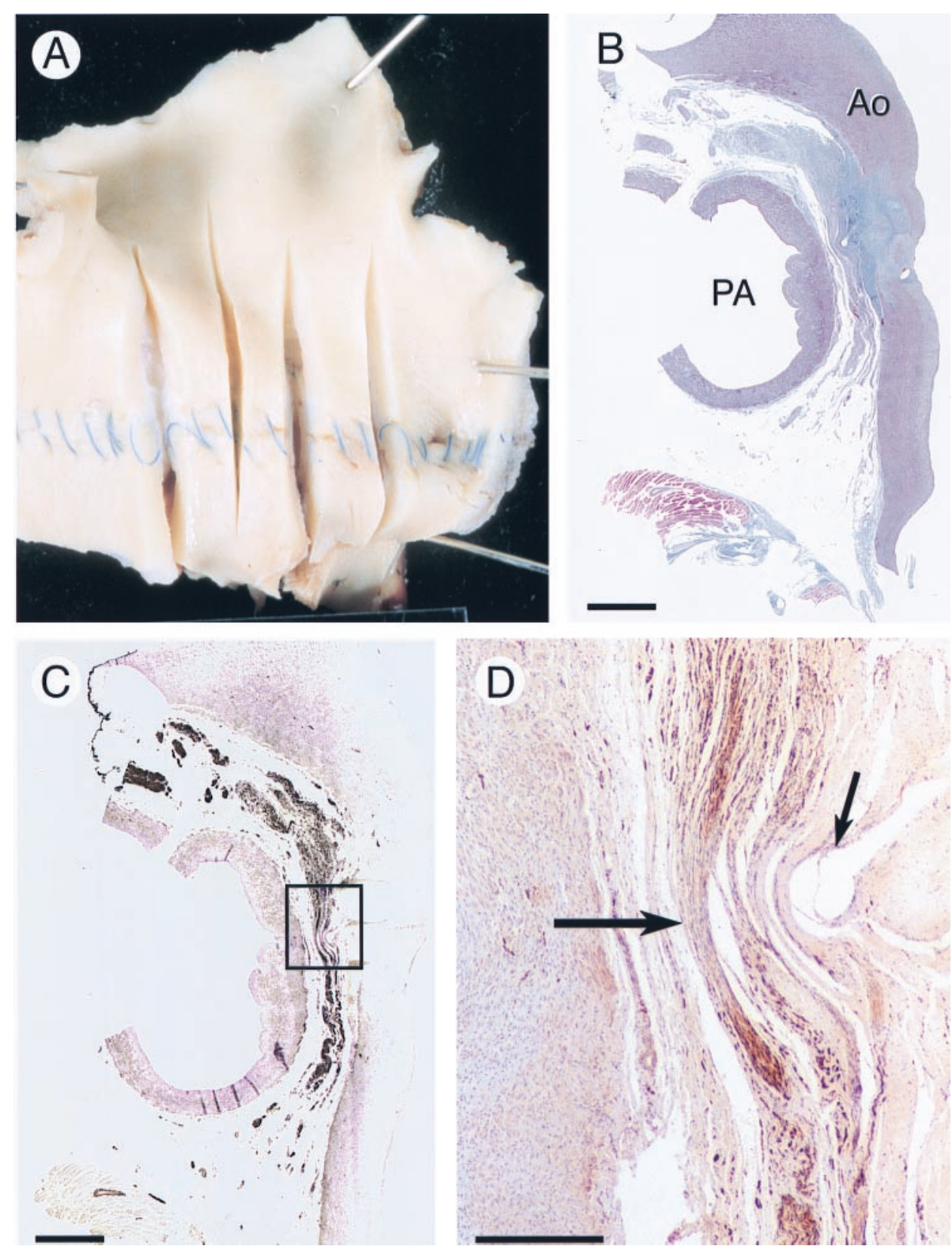

Fig 3. Gross and microscopic analyses of suture lines 1 year after transplantation. (A) Gross anatomy of suture line on intimal surface of ascending aorta. (B) Masson's trichrome stain of suture line of aorta (Ao) and pulmonary artery (PA) obtained from tissue specimen in A. (C) Neurofilament staining of same tissue demonstrating a relatively large nerve coursing over suture line to cardiac tissue at bottom of Figure. (D) Enlargement of tissue in boxed area of $\mathrm{C}$. Note the deficit where a suture was located (small arrow) and axons coursing through the suture line (large arrow). Calibration bars: $B$ and $C=10 \mathrm{~mm} ; D=2 \mathrm{~mm}$.

revealed that the aorta, pulmonary artery, and atrial tissues were fused by scarred tissue at the level of the suture line, designated by the spaces left by suture material (see Fig 3B). Employing the specific neuronal marker anti-human neurofilament protein, serial sections of these tissues demonstrated relatively large nerve bundles (maximum diameter, about $50 \mu \mathrm{m}$ ) coursing over anastomotic suture lines of the atria, aorta, and pulmonary artery (see Figs 3C, 3D). These nerve fibers were identified coursing at least $1.5 \mathrm{~cm}$ distal to suture lines and local scar tissue. Immediately cranial to the suture line, many small nerves were evident (see Fig 3D); histological evidence of traumatic injury to some of the local nerve fibers was observed. Numerous ganglia were identified in tissues caudal to the suture lines of the atria, pulmonary artery, and aorta (not shown). Relatively thick aggregations of fibrous tissue bridged epicardial surfaces of atrial suture lines. 
Table 1. Comparison of Variables Before and During Each Intervention ${ }^{a, b}$

\begin{tabular}{|c|c|c|c|c|c|}
\hline Intervention $(\mathrm{n}=9$ dogs $)$ & $\begin{array}{c}\mathrm{HR} \\
(\mathrm{bpm})\end{array}$ & $\begin{array}{c}\text { LAP } \\
(\mathrm{mm} \mathrm{Hg})\end{array}$ & $\begin{array}{l}\text { RV IMP } \\
(\mathrm{mm} \mathrm{Hg})\end{array}$ & $\begin{array}{l}\text { LV IMP } \\
(\mathrm{mm} \mathrm{Hg})\end{array}$ & $\begin{array}{c}\text { LVP } \\
\text { (mm Hg) }\end{array}$ \\
\hline Control & $103 \pm 11$ & $10 \pm 1$ & $25 \pm 3$ & $88 \pm 5$ & $120 \pm 7$ \\
\hline Right cervical vagus & $79 \pm 14$ & $10 \pm 1$ & $24 \pm 3$ & $77 \pm 11$ & $113 \pm 7$ \\
\hline Control & $114 \pm 12$ & $10 \pm 1$ & $26 \pm 3$ & $82 \pm 7$ & $117 \pm 8$ \\
\hline Left cervical vagus & $78 \pm 17$ & $10 \pm 1$ & $25 \pm 3$ & $76 \pm 8$ & $97 \pm 14$ \\
\hline Control & $108 \pm 9$ & $10 \pm 1$ & $19 \pm 2$ & $62 \pm 6$ & $109 \pm 5$ \\
\hline Right stellate ganglion & $150 \pm 13^{c}$ & $13 \pm 2$ & $37 \pm 6^{c}$ & $98 \pm 13^{c}$ & $137 \pm 11^{\mathrm{c}}$ \\
\hline Control & $119 \pm 13$ & $10 \pm 1$ & $20 \pm 2$ & $73 \pm 4$ & $104 \pm 7$ \\
\hline Left stellate ganglion & $163 \pm 9^{c}$ & $13 \pm 2$ & $48 \pm 5^{c}$ & $141 \pm 11^{\mathrm{c}}$ & $139 \pm 9^{d}$ \\
\hline Control & $122 \pm 9$ & $9 \pm 1$ & $23 \pm 3$ & $99 \pm 4$ & $104 \pm 4$ \\
\hline Nicotine, SVC & $127 \pm 7$ & $14 \pm 2$ & $36 \pm 5^{c}$ & $133 \pm 9^{c}$ & $150 \pm 16^{\mathrm{c}}$ \\
\hline Control & $127 \pm 10$ & $9 \pm 1$ & $20 \pm 1$ & $72 \pm 7$ & $112 \pm 6$ \\
\hline Nicotine, local coronary artery & $141 \pm 8$ & $9 \pm 1$ & $33 \pm 4^{\mathrm{c}}$ & $85 \pm 9^{c}$ & $125 \pm 8^{\mathrm{c}}$ \\
\hline Control & $113 \pm 10$ & $9 \pm 1$ & $28 \pm 1$ & $103 \pm 3$ & $105 \pm 5$ \\
\hline Angiotensin II, SVC & $118 \pm 8$ & $17 \pm 3$ & $50 \pm 9^{d}$ & $173 \pm 12^{c}$ & $199 \pm 13^{c}$ \\
\hline Control & $118 \pm 13$ & $8 \pm 1$ & $20 \pm 1$ & $72 \pm 5$ & $103 \pm 7$ \\
\hline Angiotensin II, local coronary artery & $117 \pm 9$ & $14 \pm 3$ & $47 \pm 11^{\mathrm{d}}$ & $135 \pm 13^{c}$ & $174 \pm 18^{\mathrm{c}}$ \\
\hline Control & $112 \pm 9$ & $9 \pm 1$ & $24 \pm 2$ & $73 \pm 7$ & $108 \pm 5$ \\
\hline Tyramine, SVC & $137 \pm 13^{c}$ & $8 \pm 1$ & $40 \pm 7^{\mathrm{d}}$ & $107 \pm 10^{c}$ & $150 \pm 10^{\mathrm{d}}$ \\
\hline Control & $109 \pm 10$ & $8 \pm 1$ & $26 \pm 7$ & $78 \pm 5$ & $111 \pm 7$ \\
\hline Tyramine, local coronary artery & $144 \pm 8^{\mathrm{c}}$ & $11 \pm 2$ & $42 \pm 8^{c}$ & $130 \pm 11^{c}$ & $144 \pm 9^{c}$ \\
\hline
\end{tabular}

${ }^{a}$ Data were compared using two-tailed paired $t$ test and are shown as the mean \pm the standard error of the mean as determined by analysis of variance. $\quad b^{b}$ The following interventions were performed: stimulating the distal ends of sectioned right and left cervical vagosympathetic complexes (cervical vagi); stimulating right and left stellate ganglia; infusion of nicotine, angiotensin II, and tyramine into bloodstream in the superior vena cava or the regional coronary arterial blood supply of the right atrial ganglionated plexus (local coronary artery). ${ }^{\mathrm{c}}$ Significance: $p<0.01$. ${ }^{\mathrm{d}}$ Significance: $p<0.05$.

$\mathrm{HR}=$ heart rate; $\quad$ LAP $=$ left atrial chamber systolic pressure; $\quad$ LV IMP $=$ left ventricular intramyocardial systolic pressure; $\quad$ LVP $=$ left ventricular chamber systolic pressure; $\quad$ RV IMP = right ventricular intramyocardial systolic pressure; SVC = superior vena cava.

\section{A}

ECG
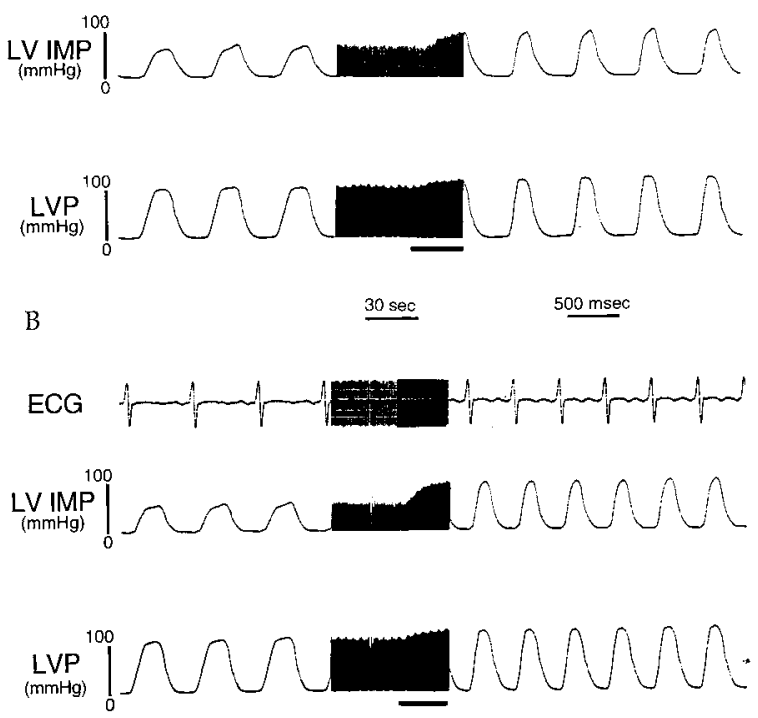

Fig 4. Cardiac effects elicited by stimulating decentralized (A) left or (B) right stellate ganglion individually in animal with substantial reinnervation. Heart rate increased during right stellate ganglion stimulation, and left ventricular systolic pressure rose when either stellate ganglion was stimulated. (ECG = lead II electrocardiogram; LV IMP = left ventricular intramyocardial pressure; LVP = left ventricular chamber pressure.)

\section{In Vivo Experiments}

ATRIAL PACING. When right atrial tissue cranial to the suture line was paced, the cranial right atrium contracted at the same rate. Atrial tissue on the caudal (distal) side of the suture line did not respond to this pacing. On cessation of pacing of right atrial tissue cranial to the suture line, the cranial atrium generated electrical activity within 1 second to 2 seconds. Electrical stimulation of right atrial tissue caudal to the suture line captured atrial tissues caudal but not cranial to the suture line. Thus, no functional electrical connectivity was found between divided atrial tissues 1 year after transplantation. After cessation of pacing ( 30 seconds) of atrial tissue caudal to the suture line, caudal atrial regions failed to generate electrical activity for $7 \pm 3$ seconds (range, 4 to 11 seconds).

CERVICAL VAGOSYMPATHETIC TRUNK STIMULATION. Six of the 9 dogs displayed varying degrees of bradycardia when the caudal end of the sectioned right or left cervical vagosympathetic trunk was stimulated electrically 1 year after transplantation. Thus, no significant changes in recorded cardiac variables were elicited overall (Table 1). Bradycardia was induced in 3 dogs when the right vagosympathetic trunk was stimulated and in 4 dogs when the left vagosympathetic complex was stimulated (see Fig 2B). 

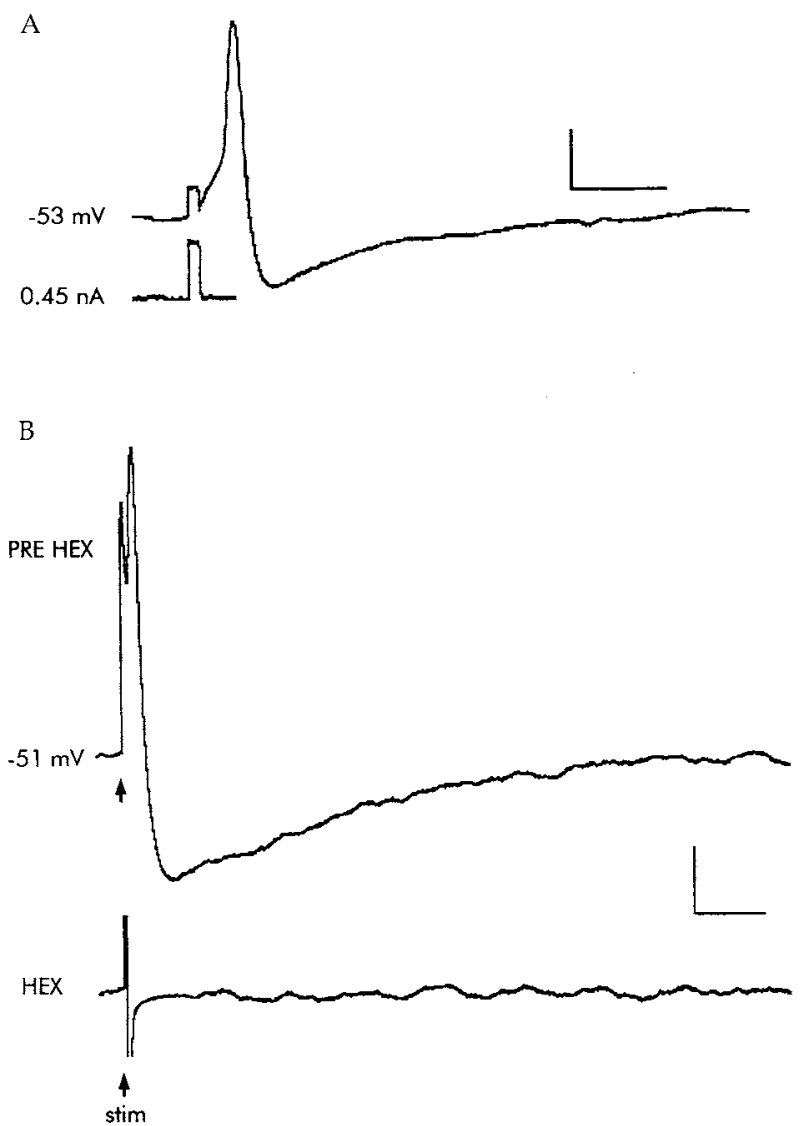

Fig 5. Responses displayed by two inferior vena cava-inferior right atrial neurons to intracellular or connecting nerve stimulation in vitro. (A) An action potential (upper trace) was generated by a depolarizing current pulse (1-ms duration) (lower trace) delivered into a neuron by way of the intracellular recording electrode. (B) A synaptically generated action potential occurred in the same neuron after stimulating a nerve (arrow stim) connected to the ganglion containing the identified neuron (arrow) before (Pre Hex) but not after (Hex) hexamethonium administration. Vertical bars: $A=10 \mathrm{mV}$; $B=20 \mathrm{mV}$; horizontal bars: $A$ and $B=10 \mathrm{~ms}$.

STELLATE GANGLION STIMULATION. Stimulation of the right or left stellate ganglion enhanced at least one monitored cardiac index in each animal studied (Fig 4). Stellate ganglion stimulation increased heart rate, right and left ventricular intramyocardial systolic pressures, and left ventricular chamber systolic pressure overall (see Table 1). Right stellate ganglion stimulation augmented heart rate in 8 of the 9 animals tested, enhancing right and left ventricular intramyocardial systolic pressures in 6 dogs. Left stellate ganglion stimulation enhanced heart rate in 6 dogs, increasing right ventricular intramyocardial systolic pressure in 8 dogs and left ventricular intramyocardial systolic pressure in all 9 dogs.

PHARMACOLOGICAL AGENTS. When nicotine was administered into superior vena caval blood, right and left ventricular intramyocardial systolic pressures increased, as did left ventricular chamber systolic pressure (see Table 1). No bradycardia or suppression of left atrial pressure occurred overall. Similar, but lesser, ventricular augmentor responses were elicited when nicotine was administered to right atrial neurons through their local coronary arterial blood supply. Nicotine also enhanced the spontaneous activity generated by ventral ventricular intrinsic cardiac neurons in the 4 animals studied.

When angiotensin II was administered either into superior vena caval blood or to right atrial neurons by way of their regional arterial blood supply, right and left ventricular intramyocardial systolic pressures increased, as did left ventricular chamber systolic pressure (see Table 1). Angiotensin II caused the greatest augmentation of ventricular contractile force. It also increased the activity generated by transplanted intrinsic cardiac neurons in the 4 animals studied.

Superior vena caval or local arterial administration to right atrial neurons of tyramine increased heart rate as well as right and left ventricular intramyocardial systolic pressures and left ventricular chamber systolic pressure (see Table 1). Tyramine increased intrinsic cardiac neuronal activity in the 4 animals studied.

\section{In Vitro Experiments}

The mean resting membrane potential of seven transplanted intrinsic cardiac neurons studied in vitro was $-52 \pm 4 \mathrm{mV}$. Mean whole-cell input resistance, as estimated by the slope of the current-voltage relationships during intracellular injections of hyperpolarization current pulses, was $151 \pm 13 \mathrm{M} \Omega$. Their mean membrane constant, calculated by the response characteristics to small hyperpolarizing current injections, was $9.1 \pm 0.7 \mathrm{~ms}$. The action potentials induced by brief ( $2 \mathrm{~ms}, 0.45 \mathrm{nA})$ depolarizing

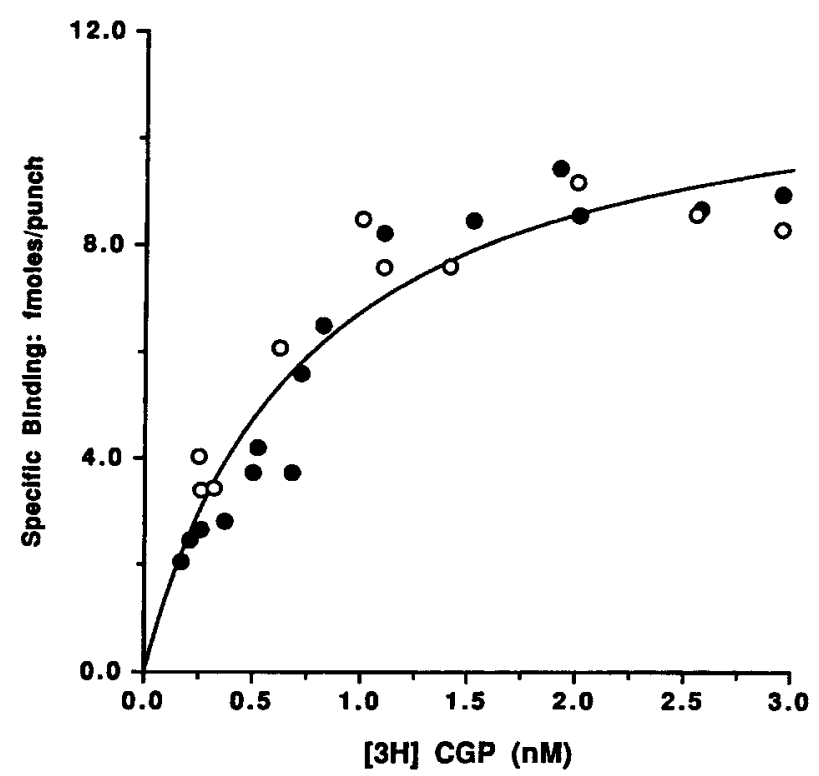

Fig 6. Saturable specific binding of [ $\left.{ }^{3} \mathrm{H}\right] \mathrm{CGP12177}$ to tissues $(2 \mathrm{~mm}$ in diameter, $350 \mu \mathrm{m}$ thick) obtained from left ventricles of control $(\bigcirc)$ and transplanted $(\bigcirc)$ hearts. Combined data derived from the ventricles of 4 study dogs and 3 control dogs are shown. 


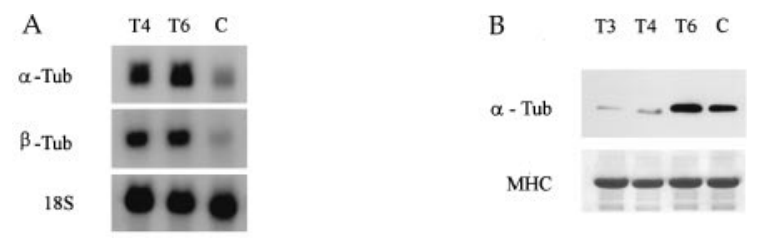

Fig 7. (A) Northern blot analysis was performed using specific complementary DNA probes; $18 \mathrm{~S}$ ribosomal RNA was used as an internal control. Expression levels of messenger RNA for both $\alpha$-tubulin $(\alpha$-Tub) and $\beta$-tubulin ( $\beta$-Tub) were augmented in myocardial tissues obtained from two transplanted hearts (T4, T6) compared with levels in control heart tissue (C). Myocardial tissue mRNA was substantially degraded in tissues obtained from a third animal (ie, T3; blot not shown). (B) Immunoblot analysis of tissue from the same myocardium demonstrating either a substantial decrease (ie, T3, T4) or no change (ie, T6) in total tubulin levels compared with control myocardial tissue. Myosin heavy chain (MHC) from a corresponding Coomassie blue-stained gel is also shown.

current pulses indicated that neurons were capable of generating after-hyperpolarizations (Fig 5A). Mean amplitude of these after-hyperpolarizations was $10 \pm 2 \mathrm{mV}$, with an average duration of $140 \pm 17 \mathrm{~ms}$. When relatively prolonged (up to 1 second) intracellular depolarizing currents were delivered to these neurons, four displayed phasic activity and three, frequency accommodation.

Investigated neurons generated action potentials when electrical stimuli ( 1 to $4 \mathrm{~mA}, 0.1 \mathrm{~ms}, 0.01 \mathrm{~Hz}$ ) were delivered to at least one of the nerves connected to the ganglia in which they lay (Fig 5B). When a single constant-current stimulus was delivered at threshold to at least one nerve, individual excitatory postsynaptic potentials were generated. Increasing the stimulus current produced action potentials that exhibited time courses and amplitudes similar to those obtained by direct intracellular current injections. That such responses were orthodromic in nature was confirmed by the fact they were no longer elicited when the bathing fluid contained low calcium $(<1 \mathrm{mmol} / \mathrm{L})$ and high magnesium (10 $\mathrm{mmol} / \mathrm{L})$, a combination of chemicals that blocks presynaptic release of neurotransmitters. After these chemicals were washed out of the bath, the nicotine receptorblocking agent hexamethonium $(100 \mu \mathrm{mol} / \mathrm{L})$ was added to the bathing medium. Stimuli delivered to the same nerve that had previously induced action potentials no longer induced action potentials in each of the dogs studied (see Fig 5B). One preparation that exhibited nicotine-dependent synapses was derived from a dog that showed no functional reinnervation of the intrinsic cardiac nervous system by right- or left-sided parasympathetic efferent preganglionic neurons.

\section{Tissue Catecholamine Content}

Left ventricular tissues contained low or undetectable levels of norepinephrine and epinephrine. On average, the norepinephrine content of these tissues was $150 \pm 70$ $\mathrm{ng} / \mathrm{g}$, ranging from undetectable levels ( $\mathrm{n}=4 \mathrm{dogs})$ to $602 \mathrm{ng} / \mathrm{g}$ of tissue. Left ventricular epinephrine content was, on average, $24 \pm 21 \mathrm{ng} / \mathrm{g}$ of tissue, being undetectable $(<0.8 \mathrm{ng} / \mathrm{kg})$ in 7 of 9 animals and $21 \mathrm{ng} / \mathrm{g}$ and 217 $\mathrm{ng} / \mathrm{g}$ in the other 2 animals. The levels of norepinephrine detected in ventricular tissues did not reflect the amount of functional reinnervation of the ventricles by sympathetic efferent neurons. For instance, the norepinephrine content of the left ventricle of the dog that generated the greatest augmentation of ventricular contractile force when intrathoracic extracardiac sympathetic efferent neurons were stimulated (see Fig 4) was $1 \mathrm{ng} / \mathrm{g}$ of tissue.

\section{Ventricular Myocyte $\beta$-Adrenergic Receptor Analysis}

Binding of $\left[{ }^{3} \mathrm{H}\right] \mathrm{CGP} 12177$ to transplanted ventricular myocardial tissue was saturable, with $\beta$-adrenergic receptor density and affinity being similar to those found in ventricular tissues obtained from dogs with normally innervated hearts. Maximum specific binding for CGP did not differ in ventricular tissues obtained from intact (12.2 \pm 1.2 femtomoles per tissue sample) versus transplanted (10.5 $\pm 0.7 \mathrm{fmol} /$ tissue sample; $\mathrm{p}=$ not significant compared with control tissues) heart tissues (Fig 6). The $\mathrm{K}_{\mathrm{D}}$ values were also similar in both groups $(0.9 \pm 0.2$ $\mathrm{nmol} / \mathrm{L}$ in control hearts; $0.5 \pm 0.1 \mathrm{nmol} / \mathrm{L}$ in transplanted hearts). Nonspecific binding, determined in the presence of timolol $\left(10^{-5} \mathrm{~mol} / \mathrm{L}\right)$, ranged from approximately $10 \%$ at $0.2 \mathrm{nmol} / \mathrm{L}$ to $17 \%$ to $20 \%$ at $2.5 \mathrm{nmol} / \mathrm{L}$. Combined data derived from the ventricles of 4 study and 3 control dogs are shown in Figure 6.

\section{Tubulin Content}

Myocardial messenger RNA (mRNA) expression of $\alpha$ and $\beta$-tubulin in ventricular tissue derived from control hearts $(n=2)$ and hearts 1 year after autotransplantation $(n=3)$ was assessed by Northern blot analysis. The $\alpha$ and $\beta$-tubulin mRNA levels were elevated substantially in two of the three transplanted hearts compared with normal hearts (Fig 7A). In the other heart, mRNA was degraded significantly compared with the untreated hearts. Total myocardial $\alpha$-tubulin protein levels were found to be substantially reduced in two of the three transplanted hearts examined (Fig 7B). Further, myocardial $\alpha$-tubulin protein content did not correlate to the levels of mRNA expression identified in these tissues. In the transplanted heart in which mRNA was degraded (ie, T3), myocardial $\alpha$-tubulin protein levels were lower than those in control hearts. In the transplanted heart in which ventricular $\alpha$-tubulin protein levels were increased compared with levels in control ventricular tissues (see Figs 7A, 7B; T6), the levels of mRNA expressed were greater than those found in control tissues (see Figs 7A, 7B; T6). Variations in $\alpha$-tubulin content so identified did not correlate with cardiac function 1 year after transplantation with respect to the capacity of the left ventricle to generate pressure or responses elicited by activation of cardiac sympathetic efferent neurons. The ventricular myocyte heavy chain standard identified was similar in normal and transplanted heart tissues (see Fig 7B).

\section{Comment}

The results of these experiments support published findings that indicate that sympathetic $[11,15]$ and parasym- 
pathetic $[10,15]$ efferent neurons reinnervate the mammalian heart by 1 year after cardiac transplantation. However, the autonomic neuronal reinnervation patterns displayed by transplanted hearts were neither uniform nor, by any means, complete as is so often characterized in the literature [8]. Rather, the degree of functional reinnervation of transplanted hearts displayed by autonomic efferent neurons varied considerably from animal to animal. Also, the degree to which hearts were reinnervated was not reflected by heart rate variability in the conscious state or by ventricular tissue catecholamine content. Finally, the intrinsic cardiac nervous system apparently remodels itself functionally in response to such altered extracardiac neuronal inputs, thus retaining some of its ability to modify regional cardiac function.

There is a growing body of evidence, derived in large part from power spectral analysis of heart rate variability, that indicates that the human heart becomes reinnervated by adrenergic efferent neurons within a few months after transplantation [14, 15]. Such presumed reinnervation can account for respiratory-related sinus arrhythmias generated by transplanted human hearts [12]. However, sympathetic efferent postganglionic neurons are located not only in mammalian intrathoracic extracardiac ganglia, but also within the intrinsic cardiac nervous system [19]. Cardiac augmentor responses elicited by chemicals such as nicotine after acute cardiac transplantation have been ascribed to the presence of intrinsic cardiac adrenergic neurons that innervate transplanted cardiomyocytes [20]. Thus, respiratory-related changes in heart rate occurring in transplanted hearts may be due, in part, to the presence of a viable intrinsic cardiac nervous system. This concept is supported by the fact that acutely [18] or chronically [17] decentralized intrinsic cardiac neurons receive respiratory-related inputs from ventricular sensory axons. For that reason, respiratory-related heart rate variability may not be an appropriate index to determine the presence or magnitude of cardiac reinnervation. In other words, it is important to analyze the functional innervation of the heart as directly as possible before determining cardiac reinnervation after transplantation.

The distribution of power spectra of heart rate variability of transplanted hearts changes in part because of the capacity of sympathetic and parasympathetic efferent neurons in extracardiac sites to influence sinoatrial node function [22]. That the autotransplanted heart retains a functional intrinsic cardiac nervous system suggests that heart rate variability after cardiac transplantation may be related not only to reinnervation patterns but also to the influence of local (intrinsic) cardiac neurons. Given the variable degree of cardiac reinnervation found in each animal in our study, particularly with respect to vagal efferent neuronal innervation patterns, power spectral analysis of heart rate variability may not be an adequate method to assess cardiac reinnervation by extracardiac efferent neurons.

Continuous 24-hour monitoring of the ECG indicated that heart rates of control $(84 \pm 19 \mathrm{bpm})$ and transplanted $(80 \pm 12 \mathrm{bpm})$ hearts were, on average, similar. However, autotransplanted hearts generated much greater heart rate variability than did hearts in monitored control animals. In agreement with that, the pacemaker complexes of transplanted atria were found to be inherently unstable. When atrial pacemaker stability was assessed by overdrive suppression (atrial pacing), pacemakers cranial to the suture line were suppressed for only 1 second to 2 seconds after termination of pacing (30 seconds). Conversely, pacemakers caudal to the suture line reestablished their activity 7 seconds after termination of atrial pacing. This property may account for the presence of the relatively prolonged periods of bradydysrhythmias displayed by transplanted atria and likewise account, in part, for residual variability in the heart rate power spectra identified in animals having transplantation.

In agreement with the finding that major nerves were identified coursing over suture lines (see Fig 3), sympathetic efferent neurons located on either side of the thorax influenced cardiodynamics whether activated electrically or chemically (see Table 1; Fig 4). However, the degree to which chronotropism became enhanced was less than that found in control hearts [23]. In accord with that, the heart rates of normal anesthetized openchest dogs $(156 \pm 10 \mathrm{bpm})$ are greater than those displayed by transplanted hearts studied in anesthetized open-chest preparations $(103 \pm 11 \mathrm{bpm})$. Similarly, although left stellate ganglion stimulation enhanced right ventricular intramyocardial systolic pressure by $280 \%$ in the intact state [23], it enhanced that index by only $140 \%$ in the transplanted state (see Table 1). Conversely, the increase in left ventricular intramyocardial systolic pressure induced by left stellate ganglion stimulation was relatively similar in intact $(+107 \%)$ [23] and transplanted $(93 \%)$ hearts (see Table 1$)$. These data support the concept that sympathetic efferent neurons display differential ventricular reinnervation patterns after cardiac transplantation [24].

That the capacity of sympathetic efferent neurons to affect cardiodynamics varied depending on the cardiac region studied could not have been due to changes in cardiac myocyte $\beta$-adrenergic receptor density and affinity because such receptors were found to be normal in transplanted ventricular tissues (see Fig 6). In accord with previous data [10, 25], ventricular tissue norepinephrine content was much lower than is normally found, being undetectable in 4 of the animals studied. Variations in ventricular tissue catecholamine levels did not reflect the differing ventricular augmentor responses elicited in different animals during sympathetic efferent neuronal stimulation. Such data suggest that tissue catecholamine content, although reduced in transplanted hearts, is not a reliable index to assess functional reinnervation of the myocardium by adrenergic efferent neurons.

Tyramine, when administered intravenously or into a coronary artery, induces the release of norepinephrine from myocardial tissues after transplantation [11]. Tyramine reportedly does not induce the release of sufficient amounts of norepinephrine from sympathetic efferent postganglionic nerve terminals in transplanted human 
hearts to influence regional cardiodynamics [26]. As right and left ventricular contractility was enhanced by tyramine 1 year after transplantation (see Table 1), ventricular sympathetic efferent postganglionic axons are still capable of releasing norepinephrine in sufficient quantities to exert considerable influence over regional cardiodynamics in such a state.

Northern blot analysis of mRNA revealed that myocyte $\alpha$ - and $\beta$-tubulin content was greater in transplanted than control ventricular tissues (see Fig 7A). These data indicate that ventricular tissue displays a greater capacity for protein synthesis after transplantation than is found in normal tissues. On the other hand, transplanted ventricular myocyte tubulin protein content, as assessed by Western blot, was less than that of normal tissue (see Fig 7B). Comparative cardiac myocyte heavy chain standards were similar in these states. These data suggest that transplanted cardiac myocytes have less tubulin than controls despite the fact that their capacity to synthesize $\alpha$-tubulin is not depressed; if anything, it is enhanced. That myocardial total tubulin content can alter after cardiac transplantation is in accord with the fact that the ventricular contractile state of transplanted hearts 1 year after transplantation was unstable; for instance, placement of a catheter in the coronary sinus was not tolerated.

Electrical stimulation of parasympathetic efferent preganglionic axons in cervical vagi failed to suppress heart rate or other monitored cardiac indices significantly overall (see Table 1). Nevertheless, bradycardia was elicited when the distal end of one or the other cervical vagal nerve was stimulated electrically in 6 of the 9 dogs studied. In some animals, considerable bradycardia was induced (see Fig 2B). Minor suppression of ventricular wall and chamber systolic pressures occurred in 2 animals when parasympathetic efferent axons were stimulated electrically (see Fig 2B). These data indicate that vagal efferent preganglionic neurons can reinnervate ventricular tissue as well as atrial tissue after cardiac transplantation and does so with considerable variability.

That angiotensin II was capable of activating intrinsic cardiac neurons 1 year after transplantation in a fashion similar to that which occurs in intact hearts [27] indicates that intrinsic cardiac neurons retain their sensitivity to angiotensin II in such a state. Angiotensin II-sensitive neurons induced greater enhancement of ventricular intramyocardial systolic pressure than did nicotinesensitive neurons (see Table 1), something that is not found in intact hearts [20,27]. In fact, bradycardia was not induced by local or systemic vascular administration of nicotine in dosages that cause it in acutely decentralized hearts [20]. These data indicate that nicotine-sensitive intrinsic cardiac neurons that innervate pacemaker cells, for instance, exert less depressor effects in the transplanted state than normally happens. Thus, functional remodeling of the intrathoracic cardiac nervous system occurs after cardiac transplantation.

Consistent with the finding that parasympathetic efferent neurons did not exert significant regulatory effects on cardiac myocytes overall (see Table 1), nicotine failed to induce cardiodepressor responses such as occur in the intact state [23]. This may have been due to the fact that the cholinergic efferent component of the intrinsic cardiac nervous system was functionally obtunded a year after cardiac transplantation. Despite this, intrinsic cardiac neurons obtained from transplanted hearts studied in vitro displayed similar transmembrane electrical properties as those displayed by normally innervated intrinsic cardiac neurons [28]. Transplanted intrinsic cardiac neurons retained their functional synaptic inputs as well (see Fig 5A). Some of these were cholinergic in nature because they were abolished after application of the nicotineblocking agent hexamethonium (see Fig 5B). That nicotine-sensitive and angiotensin II-sensitive adrenergic neurons located in intrathoracic extracardiac ganglia modify regional cardiodynamics must be considered with respect to the cardiac responses that pharmacologic agents induce in the transplanted state.

Taken together, these data indicate the following eight points: Adrenergic neurons reinnervate the canine heart within 1 year after transplantation. Parasympathetic efferent neurons reinnervate the transplanted heart to a lesser extent, being absent in some cases. After cardiac transplantation, the intrinsic cardiac nervous system remodels itself to sustain cardiac function, becoming more responsive to angiotensin II than nicotine. Transplanted atrial pacemakers display instability after cardiac transplantation. Heart rate variability after cardiac transplantation bears little or no relationship to the degree or type of autonomic efferent neuronal reinnervation, and consequently, power spectral analysis may not be an adequate indicator of the magnitude or type of functional cardiac reinnervation. Ventricular tissue catecholamine content is not directly indicative of the degree of functional reinnervation by cardiac sympathetic efferent neurons. Cell surface $\beta$-adrenergic receptor density and affinity in transplanted ventricular tissues are similar to those in nontransplanted tissues and thus are not a good index of functional reinnervation. Cardiac myocyte structural proteins become altered after cardiac transplantation.

The clinical implications of our findings are as follows: Remodeling of the intrinsic cardiac nervous system should be taken into consideration when studying the functional status of the heart after transplantation. Direct assessment of cardiac neuronal function is required to depict the functional status of the cardiac nervous system after cardiac transplantation.

The technical assistance of Richard Livingston, Elen Tremaine, Cheryl Forbes, Rick Leadon, Elizabeth Charuvastra, Roger Basket, and Paul Wilkinson is gratefully acknowledged.

This work was supported by the Medical Research Council of Canada (MT 10122), the Québec, Nova Scotia, and New Brunswick Heart and Stroke Foundations, the National Institutes of Health, (grant HL58140) and the Maritime Heart Center. 


\section{References}

1. Arrowood JA, Goudreau E, Minisi AJ, Davies AB, Mohanty PK. Evidence against reinnervation of cardiac vagal afferents after human orthotopic cardiac transplantation. Circulation 1995;92:402-8.

2. Arrowood JA, Minisi AJ, Goudreau E, Davies AB, King AL. Absence of parasympathetic control of heart rate after human orthotopic cardiac transplantation. Circulation 1997;96: 3492-8.

3. Cannom DS, Graham AF, Harrison DC. Electrophysiological studies in the denervated transplanted human heart. Circ Res 1973;32:268-78.

4. Donald DE, Shepherd JT. Response to exercise in dogs with cardiac denervation. Am J Physiol 1963;205:393-400.

5. Donald DE, Milburn SE, Shepherd JT. Effect of cardiac denervation on the maximal capacity for exercise in the racing greyhound. J Appl Physiol 1964;19:849-52.

6. Rowan RA, Billingham ME. Myocardial innervation in longterm heart transplant survivors: a quantitative ultrastructural survey. J Heart Lung Transplant 1988;7:448-52.

7. Kresh JY, Izrailtyan I. Evolution in functional complexity of heart rate dynamics: a measure of cardiac allograft adaptability. Am J Physiol 1998;275:R720-7.

8. Kaye MP, Randall WC, Hageman GR, Geis WP, Priola DV Chronology and mode of reinnervation of the surgically denervated canine heart: functional and chemical correlates. Am J Physiol 1977;233:H431-7.

9. Kontos HA, Thames MD, Lower RR. Responses to electrical and reflex autonomic stimulation in dogs with cardiac transplantation before and after reinnervation. J Thorac Cardiovasc Surg 1970;59:382-92.

10. Willman VL, Cooper T, Cian L, Hanlon CR. Neural responses following autotransplantation of the canine heart. Circulation 1963;27:713-6.

11. Wilson RF, Christensen BV, Olivari MT, Simon A, White $\mathrm{CW}$, Laxson DD. Evidence for sympathetic reinnervation after orthotopic cardiac transplantation in humans. Circulation 1991;83:1210-20.

12. Sands KE, Appel ML, Lilly LS, Schoen FJ, Mudge GH Jr, Cohen RJ. Power spectral analysis of heart rate variability in human cardiac transplant recipients. Circulation 1989;79: $76-82$.

13. Bernardi L, Valle F, Leuzzi S, et al. Non-respiratory components of heart rate variability in heart transplant recipients: evidence of autonomic reinnervation? Clin Sci (Colch) 1994; 86:537-45.

14. De Marco T, Dae M, Yuen-Green MS, et al. Iodine-123 metaiodobenzylguanidine scintigraphic assessment of the transplanted human heart: evidence for late reinnervation. J Am Coll Cardiol 1995;25:927-31.

15. Tio RA, Reyners AKL, van Velduisen DJ, et al. Evidence for
CARDIAC REINNERVATION AFTER TRANSPLANTATION

differential sympathetic and parasympathetic reinnervation after heart transplantation in humans. J Auton Nerv Syst 1997;67:176-83.

16. Blomquist TM, Priola DV, Romero AM. Source of intrinsic innervation of canine ventricles: a functional study. Am J Physiol 1987;252 (3 Pt 2):H638-44.

17. Ardell JL, Butler CK, Smith FM, Hopkins DA, Armour JA. Activity of in vivo atrial and ventricular neurons in chronically decentralized canine hearts. Am J Physiol 1991;260 (3 Pt 2):H713-21.

18. Armour JA, Hopkins DA. Activity of in vivo canine ventricular neurons. Am J Physiol 1990;258 (2 Pt 2):H326-36.

19. Butler CK, Smith FM, Cardinal R, Murphy DA, Hopkins DA, Armour JA. Cardiac responses to electrical stimulation of discrete loci in atrial and ventricular ganglionated plexi. Am J Physiol 1990;259:H1365-73.

20. Murphy DA, O'Blenes S, Hanna BD, Armour JA. Capacity of intrinsic cardiac neurons to modify the acutely autotransplanted mammalian heart. J Heart Lung Transplant 1994;13: 847-56.

21. Berger RD, Saul JP, Cohen RJ. Transfer function analysis of autonomic regulation: canine atrial rate response. Am J Physiol 1989;256:H142-52.

22. Meyer M, Marconi C, Ferretti G, Fiocchi R, Cerretelli P, Skinner JE. Heart rate variability in the human transplanted heart: nonlinear dynamics and QT vs RR-QT alterations during exercise suggest a return of neurocardiac regulation in long-term recovery. Integr Physiol Behav Sci 1996;31:289_ 305.

23. Murphy DA, O’Blenes S, Hanna BD, Armour JA. Functional capacity of nicotine-sensitive canine intrinsic cardiac neurons to modify the heart. Am J Physiol 1994;266 (4 Pt 2):R1127-35.

24. Wilson RF, Laxson DD, Christensen BV, McGinn AL, Kubo $\mathrm{SH}$. Regional differences in sympathetic reinnervation after human orthotopic cardiac transplantation. Circulation 1993; $88: 165-71$.

25. Regitz V, Bossaller C, Strasses R, Schuler S, Hetzer R, Fleck E. Myocardial catecholamine content after cardiac transplantation. Circulation 1990;82:620-3.

26. Stark RP, McGinn AL, Wilson RF. Chest pain in cardiactransplant recipients. Evidence of sensory reinnervation after cardiac transplantation. N Engl J Med 1991;324:1791-4.

27. Horackova M, Armour JA. ANG II modifies cardiac function via intrathoracic extracardiac and intrinsic cardiac neurons: in situ and in vivo studies. Am J Physiol 1997;272 (3 Pt 2):R766-75.

28. Smith FM, Hopkins DA, Armour JA. Electrophysiological properties of in vitro intrinsic cardiac neurons in the pig (Sus scrofa). Brain Res Bull 1992;28:715-25. 